\title{
Meat Quality of the Native Carpathian Goat Breed in Comparison with the Saanen Breed
}

\author{
Władysław Migdał $^{1}{ }^{(\mathbb{D}}$, Aldona Kawęcka ${ }^{2, * \mathbb{D}}$, Jacek Sikora ${ }^{2}$ and Lukasz Migdał ${ }^{3}$ \\ 1 Department of Animal Product Processing, University of Agriculture in Krakow, ul. Balicka 122, \\ 30-149 Krakow, Poland; wladyslaw.migdal@urk.edu.pl \\ 2 Department of Sheep and Goat Breeding, National Research Institute of Animal Production, ul. Krakowska 1, \\ 32-083 Balice, Poland; jacek.sikora@iz.edu.pl \\ 3 Department of Genetics, Animal Breeding and Ethology, University of Agriculture in Krakow, al. \\ Mickiewicza 24/28, 30-059 Krakow, Poland; lukasz.migdal@urk.edu.pl \\ * Correspondence: aldona.kawecka@iz.edu.pl
}

check for

updates

Citation: Migdał, W.; Kawęcka, A.; Sikora, J.; Migdał, Ł. Meat Quality of the Native Carpathian Goat Breed in Comparison with the Saanen Breed. Animals 2021, 11, 2220. https:// doi.org/10.3390/ani11082220

Academic Editors: Virgínia Alice Cruz Dos Santos, Severiano R. Silva and Cristina Miranda Guedes

Received: 1 July 2021

Accepted: 25 July 2021

Published: 27 July 2021

Publisher's Note: MDPI stays neutral with regard to jurisdictional claims in published maps and institutional affiliations.

Copyright: (c) 2021 by the authors. Licensee MDPI, Basel, Switzerland. This article is an open access article distributed under the terms and conditions of the Creative Commons Attribution (CC BY) license (https:/ / creativecommons.org/licenses/by/ $4.0 /)$.
Simple Summary: The aim of this study was to investigate the influence of male goat kid breeds on the basic chemical, fatty and amino acid composition, colour and sensory evaluation of fresh meat. The meat of the Carpathian kids was characterised by a lower content of protein and cholesterol, and a higher content of fat. Despite the higher collagen content, the meat was characterised by lower shear force, less hardness and chewiness, being a more delicate meat compared to the meat from Saanen goats. The meat of native goats was higher concerning the content of phenylalanine, histidine, proline, alanine and tyrosine, as compared to the meat of the Saanen goats. The fat of Carpathian goat meat was characterised by a higher content of monounsaturated acids and a more favourable (lower) saturation index.

Abstract: Goats provide valuable products that are appreciated by consumers who are looking for food that is not only tasty but also healthy, and, probably, one of them is goat meat. Breeding of local breeds such as the native Carpathian goat has been gaining importance in recent years, which creates an opportunity for the development of the goat meat market. The aim of this study was to investigate the influence of goat breed on the basic chemical, fatty and amino acid composition, colour and sensory evaluation of meat. The research material consisted of Carpathian goats from the NRIAP experimental plant located in the southern part of Poland, and goats from a farm keeping Saanen goats in south-eastern Poland. Ten male goat kids from each breed were taken to the NRIAP farm. The quality of meat obtained from the leg ( $m$. biceps femoris) of male goat kids about 150 days old at slaughter was analysed. The meat of the Carpathian goat was characterised by a lower content of protein and cholesterol $(p<0.01)$, and a higher content of fat and general collagen compared to the meat from Saanen goats $(p<0.05)$. Cholesterol content in goat meat of both breeds was similar and ranged from $55.08 \mathrm{mg} / 100 \mathrm{~g}$ (Carpathian) to $56.79 \mathrm{mg} / 100 \mathrm{~g}$ (Saanen). Despite the higher collagen content, the goat meat of Carpathian breeds was characterised by lower shear force, less hardness $(p<0.05)$ and chewiness, being a more delicate meat. The fat of Carpathian goat breeds was characterised by a higher content of monounsaturated acids, mainly C 18:1n:9, and a more favourable (lower) saturation index, $\mathrm{S} / \mathrm{P}(p<0.05)$. The meat of Carpathian goats was characterised by a higher health-promoting quality compared to the meat from Saanen goats. In the goat meat of both breeds, there were no differences between the total content of exogenous and endogenous amino acids. The essential/nonessential amino acids (EAA/NEAA) ratio in the meat of the analysed breeds was 0.88:0.89. However, the meat of the Carpathian goats was statistically significantly higher concerning the content of phenylalanine, histidine, proline, alanine and tyrosine, as compared to the meat of the Saanen goats. The obtained results confirm the high quality of the meat of the local Carpathian breed in comparison to the Saanen breed.

Keywords: male goat kids; Carpathian; Saanen; meat quality 


\section{Introduction}

The world population of goats is over 1 billion units. Only during the period from 2000 to 2013 did an important increase in goats occur worldwide (33.79\%). Among the continents, Asia constantly holds first place, having a contribution to the total goat population of $59.38 \%$ and an increase in the number of goats by $30.23 \%$ in the period $2000-2013$. Africa comes in second with a contribution of $35 \%$ and an increase during the above-mentioned period by $48.61 \%$. In Oceania, a spectacular increase was observed in the number of goats $(65.76 \%)$ during the same period. In the Americas, the increase was only $3.13 \%$, while in Europe and the E.U. (28), a relative decrease could be noted [1]. In 2017, 12.7 million goats were kept in the European Union, but goat breeding in Europe is very diverse. According to data of EUROSTAT [2] from 2018 reports, it was noted that the majority of goats were kept in Greece $(3,625,000)$, Spain $(2,764,000)$ and, in other European countries outside the EU, 10,634,000 were kept in Turkey. The goat population in Poland has undergone rapid changes - from around 800,000 in 1948, to 40,000 in 1970. Data from 2015 show that it was 58,000 pcs., which was $0.5 \%$ of all farm animals [3].

The present goat population in Poland was influenced by the old local general-purpose breeds: Carpathian, Sandomierska and Kazimierzowska. The Sandomierska and Kazimierzowska native breeds are extinct, but efforts at restoring the Carpathian breed were successful and now a small population of these goats is raised in the Sub-Carpathian area [4]. Goats kept in Poland are mostly hybrids obtained from crossing the local population with noble breeds. Of the noble breeds, the meat of the Boer breed plays a dominant role, and, of dairy breeds, the White and Coloured Improved, Saanen and Alpine breeds are dominant [5]. Saanen goats make up approximately $10 \%$ of goats entered in the herd books in Poland and their average milk yield is approximately $640 \mathrm{~kg}$ [6]. Until recently, in the Polish population, apart from the most common Polish goats, the so-called Polish Improved and Polish Coloured Improved animals with a typical dairy usage, there were local breeds (Kazimierzowska and Carpathian) and non-breed goats-general-purpose type. All-purpose breeds (milk, meat, skins) gradually lost their importance and were replaced by other, one-purpose breeds (dairy or meat) or dual-purpose types (dairy and meat), which was one of the reasons that led to the extinction of the mentioned native goats [7].

The tradition of keeping the primitive mountain Carpathian goats and Zackel sheep dates back to the Wallachian colonisation. Beginning from the 12th century, Wallach shepherds (Wallachs were an ethnic group originating from the Balkan Peninsula, living south of the Danube river) started to move with their animal herds (mainly of sheep and goats), which needed pastures, to the north along the Carpathian range, reaching the Oravia and Moravia and to the "Polish" area, the contemporary Beskids [8]. Apart from sheep and cattle, the Wallachs also grazed herds of goats with a lean body structure and a long or semi-long white or coloured coat. In the area of the Polish mountains, so-called Carpathian goats, white mountain goats, could be found. This goat was adapted to the harsh mountain conditions, used fodder very well, was resistant to diseases and had a lean body structure with low-set, strong limbs, a wide and well-arched chest and long and dense coat, allowing animals to survive in difficult conditions. Good milk yield, about $500 \mathrm{~kg}$ per year, was enough to feed their offspring and produce Wallachian cheeses [9].

The twilight of transhuman pastoralism, a negative campaign regarding goats (the poor people's animal), goat's milk and goat products, and the importation of more efficient breeds (Saanen and Toggenburg goats), contributed to the fact that in the second half of the 20th century, this breed was considered extinct. In 2006, actions were taken in an attempt to restore this breed by the National Research Institute of Animal Production Experimental Station in Odrzechowa as part of the statutory activity, using two herds of goats of the Carpathian goat type found in Poland. Two years later, a programme for the conservation of the genetic line of the Carpathian breed of goats was undertaken, and in 2010, by the decision of the Minister of Agriculture and Rural Development, the National Research Institute of Animal Production was recognised as keeping a breeding book for the Carpathian goat. This breed is of versatile utility, with an average milk 
yield of about $350 \mathrm{~kg}$. Male and female kid goats are used to produce good quality meat [10]. According to Călin et al. [11], Carpathian breed populations still have a high degree of heterogeneity, by reacting positively to improved technologies and through their performance in terms of meat production, characteristics that can be improved and used in terms of economic efficiency. Now, in Poland, Carpathian goats have the largest share in the active population [12].

The aim of the study was to analyse the physicochemical characteristics of the meat of goats from native Carpathian breeds and to compare them with the results of meat quality from goats of the Saanen breed.

\section{Materials and Methods}

\subsection{Animals and Experimental Design}

The experiment was carried out in 2019 on the farm of the National Research Institute of Animal Production (NRIAP), located in the southern part of Poland. The research material consisted of Carpathian goats from a herd of 30 dams from the NRIAP experimental plant located in the southern part of the country, and goats from a farm keeping 30 Saanen goats in south-eastern Poland. All the goats were from twins. Goats on both farms were kept with their mothers until about 60 days of age, where they received crushed oats and hay. After weaning, animals were weighed at 90 days of age and 10 goats from each breed were chosen based on average live weight and were taken to the NRIAP farm. After weaning, they were fed with good quality hay and received $300 \mathrm{~g}$ of a concentrated mixture containing: $52 \%$ barley, $20 \%$ oats, $5 \%$ wheat bran, $15 \%$ soybean meal, $5 \%$ rapeseed expeller and $3 \%$ of a mineral mixture. After weaning, the male goats were kept in two group pens $(4 \times 4 \mathrm{~m})$ by breed. The area of the pens was $1.5 \mathrm{~m}^{2}$ per animal. After 10 days of adaptation, the fattening period started, which lasted from day 100 to slaughter on day 150. During this period, they received the same concentrated mixture at the amount of $400 \mathrm{~g}$ per animal and hay at will. The animals had constant access to fresh water and licks. After fattening, animals were subjected to slaughter at an EU-licensed abattoir after $24 \mathrm{~h}$ feed withdrawal. They were stunned using a captive-bolt pistol. Procedures met the requirements of the Directive 2010/63/EU [13] of the European Parliament and of the Council of 22 September 2010 on the protection of animals used for scientific purposes. After $24 \mathrm{~h}$ of chilling at $4{ }^{\circ} \mathrm{C}$, slaughter analysis was performed according to the methodology for small ruminants prepared by the National Research Institute of Animal Production [14]. The carcasses were divided into half-carcasses, and then the right half-carcass was sectioned into cuts. The analysis included post-slaughter carcass evaluation and determination of the proportion of carcass cuts and leg tissue composition. Muscle samples were taken from the leg (m. biceps femoris) to determine chemical composition, physicochemical, texture and sensory parameters, as well as the fatty acid profile of the meat. Samples were vacuum packed in polyethylene packs and stored at $-20 \circ \mathrm{C}$ for further evaluation.

\subsection{Meat Physicochemical Properties}

Meat colour was determined using a Konica Minolta CM-600d spectrophotometer (Minolta Co., Ltd., Tokyo, Japan) with a 50-mm diameter measuring head in the CIE L*a* ${ }^{*}$ system, where the $L^{*}$ parameter corresponds to the degree of lightness $\left(L^{*}=0\right.$ : black, $\mathrm{L}^{*}=100$ : white), $\mathrm{a}^{*}$ and $\mathrm{b}^{*}$ are colour components $\left(\mathrm{a}^{*}>0\right.$ red, $\mathrm{a}^{*}<0$ green, $\mathrm{b}^{*}>0$ yellow, $b^{*}<0$ blue). The chromametre was calibrated against a white tile $(Y=93.8, x=0.3136$, $\mathrm{y}=0.3192)(\mathrm{CIE}, 1986)$.

The following items were assessed in the meat samples:

- $\quad$ water content according to the standard (PN-ISO 1442:2000) [15],

- $\quad$ fat content according to the standard (PN-ISO 1444:2000) [16],

- $\quad$ protein content by Kjeldahl method (PN-75/A-04018) [17],

- $\quad$ total ash content according to the standard (PN-ISO 936:2000) [18],

- total carbohydrate content assuming that all total solids and water stood for $100 \%$. 
The total collagen content was estimated according to Polish Standard (PN-ISO 3496:2000) [19]. The absorbance of samples was measured with Novasina spectrophotometer at $558 \mathrm{~nm}$. The hydroxyproline content was read from calibration curve. The total collagen content was calculated from hydroxyproline amount using the coefficient 7.25 and with dilution factors included.

Fatty acid profile was determined by two analytical methods: lipid extraction from meat according to Folch et al. [20] and esterification according to AOAC (1995) [21]. The fatty acid methyl esters were separated by gas chromatography using a TRACE GC ULTRA (Thermo Electron Corporation, Milano, Italy) with a flame ionisation detector (FID) via the SUPELCOWAX 10 column $(30 \mathrm{~m} \times 0.25 \mathrm{~mm} \times 0.25 \mu \mathrm{m})$. The separation conditions were as follows: helium as the carrier gas, $1 \mathrm{~mL} / \mathrm{min}$; FID detector temp. $250{ }^{\circ} \mathrm{C}$; injector temp. $220{ }^{\circ} \mathrm{C}$; oven temp. was maintained at $160{ }^{\circ} \mathrm{C}$ and increased $\left(3^{\circ} \mathrm{C} / \mathrm{min}\right)$ to $210{ }^{\circ} \mathrm{C}$ (35 min); split ratio $10 \mathrm{~mL} / \mathrm{min}$. To the obtained fat (approx. $10 \mathrm{mg}$ ), $0.5 \mathrm{~mL}$ of $0.5 \mathrm{M} \mathrm{KOH}$ in methanol was added and heated to $85^{\circ} \mathrm{C}$, after which $1 \mathrm{~mL}$ of $12 \% \mathrm{BF}_{3}$ in methanol was added and reheated at $85{ }^{\circ} \mathrm{C}$. After cooling down to room temperature, $1 \mathrm{~mL}$ of hexane and $5 \mathrm{~mL}$ of saturated $\mathrm{NaCl}$ solution were added. The solution, in the amount of $1 \mu \mathrm{L}$, was injected on the chromatograph. Individual fatty acid methyl esters (FAME) were identified by comparison with a standard mixture of 37 FAME components (Supelco, Sigma-Aldrich Co., St. Louis, MO, USA) and CLA isomers (Sigma-Aldrich Co.).

The amino acid composition was determined by means of RP-HPLC using the Waters ACCQ-Tag Ultra Derivatization kit (186003836, Waters, Milford, MA, USA). Using 4 mL of $6 \mathrm{M} \mathrm{HCl}$ and $15 \mu \mathrm{L}$ of phenol at $110^{\circ} \mathrm{C}$ for $24 \mathrm{~h}, 2 \mathrm{mg}$ of the sample were hydrolysed. The sample was sealed in a nitrogen atmosphere during the process of hydrolysis. The acquired hydrolysate was filtered using a syringe filter with a pore diameter of $45 \mu \mathrm{m}$ and dried under a constant stream of nitrogen. The samples prepared in such a way were diluted accordingly and derivatised by mixing $10 \mu \mathrm{L}$ of the sample with $70 \mu \mathrm{L}$ of boron buffer $(\mathrm{pH}$ in the range of 8.2-9.0) and $20 \mu \mathrm{L}$ of 6-aminoquinolyl-N-hydroxysuccinimidylcarbamate (AQC) in a $3 \mathrm{mg}$ concentration of ACQ/mL acetonitrile. The standards were prepared in the same manner as the samples. The separation was carried out using the Dionex Ultimate 3000 HPLC system (Thermo Scientific, Waltham, MA, USA) equipped with an LPG-3400 SD 4-channel gradient pump, WPS 3000 TSL autosampler and VWD 3400RS 4-channel UV/VIS detector. Analysis was performed using a Nova-Pak C18, $4 \mu \mathrm{m}(150 \times 3.9 \mathrm{~mm})$ column (Waters, USA). In the elution procedure, an acetate-phosphate buffer (Eluent A) and 60:40 acetonitrile/water (Eluent B) were used according to the procedure recommend by Waters (USA). The separation temperature was set at $37^{\circ} \mathrm{C}$. Detection was carried out at a $240 \mathrm{~nm}$ wavelength. Quantitative analysis was performed via 1 point calibration using analytical standards (100 pmol for each concentration).

\subsection{Texture and Sensory Evaluation}

Muscle fragments weighing around $120 \mathrm{~g}$ were packed in aluminium foil. Thermal treatment in an electric furnace was carried out at a temperature of $180 \pm 2{ }^{\circ} \mathrm{C}$ until reaching a muscle temperature of $72 \pm 2{ }^{\circ} \mathrm{C}$. The temperature inside the muscles was measured with a digital thermometer using a probe needle. After heat treatment and cooling on ice, cooking loss was determined from meat weight loss, and sensory and texture analyses were performed.

The texture profile (TPA) of the meat was analysed according to the PN-ISO Norm 11036:1999, with the TA-XT2 texture analyser (Stable Micro Systems Co. LTD., Godalming, UK). Shear force was measured from cylindrical samples (14 mm diameter, $15 \mathrm{~mm}$ height), using a Warner-Bratzler attachment (shearing blade thickness of $1.016 \mathrm{~mm}$, V-shaped cutting blade with a $60^{\circ}$ angle, corner of the $\mathrm{V}$ rounded to a quarter-round of a $2.363 \mathrm{~mm}$ diameter circle, spacers providing the gap for the cutting blade to slide of $1.245 \mathrm{~mm}$ thickness) and a triangular notch in the blade. Blade speed during the test was $1.5 \mathrm{~mm} / \mathrm{s}$. The results are presented as force per area $\left(\mathrm{kg} / \mathrm{cm}^{2}\right)$. The meat was roasted to $180{ }^{\circ} \mathrm{C}$ with an inner temperature of $78{ }^{\circ} \mathrm{C}$, then cooled to room temperature and the samples were cut out, 
parallel to the muscle fibres, as cylinders with a diameter of $16 \mathrm{~mm}$ and $15 \mathrm{~mm}$ in height. The speed of the sampling knife movement during the test was $1.5 \mathrm{~mm} / \mathrm{s}$. The results are presented as force working on the surface of the cut $\left(\mathrm{kg} / \mathrm{cm}^{2}\right)$. The analysis of texture profile was performed with the above device using a cylindrical sampling probe with a diameter of $50 \mathrm{~mm}$. The test of double pressing the meat samples was conducted up to $70 \%$ deformation of their height. The speed of cylinder movements were $2 \mathrm{~mm} / \mathrm{s}$, the interval between the 3 pressings was $3 \mathrm{~s}$, whereas the threshold of sample detection was $10 \mathrm{~g}$. TPA parameters were calculated via Texture Exponent software, version 5.1.15.0 (Stable Micro Systems). Texture (hardness, springiness, cohesiveness, chewiness) was analysed using the attached cylinder $-50 \mathrm{~mm}$ in diameter. The samples were subjected to a double pressing test, applying a force of $10 \mathrm{~g}$ to $70 \%$ of their height. The cylinder speed was $2 \mathrm{~mm} / \mathrm{s}$, and the interval between presses was $3 \mathrm{~s}$.

\subsection{Sensory Evaluation}

Sensory analysis was also performed. After roasting, the meat samples were evaluated using a scaling method according to the Polish Standards: PN-ISO 4121:1998 [22] and PNISO 6658:1998 [23]. The following features of the meat were assessed: structure, aroma, tenderness, juiciness and flavour with a 5-point scale [22]. The assessment was made by the 10 panellists consisting of employees from the Department of Animal Product Technology, University of Agriculture in Kraków, trained in goat meat sensory analysis. The panel had years of experience in sensory evaluation practice and were trained theoretically and practically regarding the applied methods [24]. The panellists rinsed their mouths with a sip of water before starting the analysis and between each sample. The meat samples were scored for the analysed characteristics on a scale from 1 (poor-lowest grade) to 5 (excellent-the highest grade) with increments of 0.5 . The final scores for different meat features were evaluated as average scores assigned by the tasters. The sensory evaluations were conducted in standard conditions, including room temperature $\left(22^{\circ} \mathrm{C}\right)$, relative humidity $65 \%$, individual booths and white light of approximately $500 \mathrm{~lx}$. Results were analysed in Panel Check v.1.4.2 (PCA; Panel Check V 1.4.2, Nofima, Norway); http: / / www.panelcheck.com, (accessed on 1 March 2021) using STATIS analysis biplot option.

\subsection{Statistical Analysis}

All samples were obtained at least in duplicates. All results were analysed with $\mathrm{t}$-Student test and presented as mean \pm standard deviation. The calculations were performed using Statistica 6.0 [25].

$$
Y_{i}=\mu+B_{i}+e_{i}
$$

where $Y_{i}$ represents the observations, $\mu$ is the overall mean, $B_{i}$ is the effect of breed ( $\left.i=1.2\right)$, $e_{i}$ represents random error.

\section{Results and Their Discussion}

The chemical composition and quality of goat meat depends, among others, on the genotype (breed), utility type, sex, age of slaughter, nutrition and breeding system [26-28]. In Table 1, the chemical composition of the kid goat meat (non-castrated) slaughtered at the age of five months belonging to two breeds: dairy Saanen and general Carpathian, is presented. The meat of the Carpathian goats was characterised by a lower content of protein and cholesterol, while the content of fat and general collagen was higher compared to the meat of the Saanen goats. According to Horoszewicz and Pieniak-Lendzion [29], white meat from a male goat kid improved breed, slaughtered at 90 days of age, contained $1.29 \%$ of fat, while the meat of goats slaughtered on the 150th day contained $2.27 \%$ of fat. Borgogno et al. [30] found $3.0 \mathrm{~g}$ lipids in $100 \mathrm{~g}$ of fresh meat (longissimus thoracis) fall chevon (5-5.5 months) kids of Alpine breed. Water/protein ratio ranged from 3.78 (Saanen) to 4.04 (Carpathian), and was similar to the results obtained by Brzostowski et al. [31] for meat of the French Alpine breed (4.18) and French Alpine $\times$ Boer goats (3.89). Cholesterol content of the goat meat of both breeds was similar and ranged from $55.08 \mathrm{mg} / 100 \mathrm{~g}$ 
(Carpathian) to $56.79 \mathrm{mg} / 100 \mathrm{~g}$ (Saanen). By slaughtering 50-day-old French Alpine goats, Brzostowski et al. [31] found lower fat $(1.67 \%)$ and cholesterol $(48.76 \mathrm{mg})$ content in the meat (quadriceps muscle of the thigh ( $m$. quadriceps femoris). In an experiment carried out by Kalinowska et al. [32] on kids fattened to a body mass of $16 \mathrm{~kg}$, the cholesterol content in the longest spinae muscle was $61.31 \mathrm{mg}$ in $100 \mathrm{~g}$, while in the study by Patli et al. [33], the content of cholesterol in the muscle tissue ranged from 70 to $120 \mathrm{mg} / 100 \mathrm{~g}$. Madruga et al. [27] showed the effects of the age of slaughter and castration on the content of cholesterol in the muscles of the studied goat kids. In the meat of goats castrated and slaughtered at different ages, i.e., 175 days, 220 days, 265 days and 310 days, the highest cholesterol content was found in the muscles of the oldest animals- $74 \mathrm{mg}$ in $100 \mathrm{~g}$, and the lowest cholesterol content in the group of kids slaughtered at 220 days- $51.8 \mathrm{mg}$ in $100 \mathrm{~g}$. The meat of the castrated animals contained $62.5 \mathrm{mg}$ in $100 \mathrm{~g}$ and non-castrated, $58 \mathrm{mg}$ of cholesterol per $100 \mathrm{~g}$. In addition, the meat from castrated animals had a higher fat content. Despite the lower protein content, Carpathian goat meat had a higher total collagen content compared to meat from the Saanen goats. A similar collagen content of $0.40-0.45 \%$ was noted by Marichal et al. [34] in the meat from kids of the Canary Caprine Group Breed. Stanisic et al. [35] indicated that in the meat of crossbred kid goats (Balkan $\times$ Saanen goat), along with the increase in the share of Saanen genes, the level of fat and collagen increased, while the level of protein decreased. In addition, along with the increase in the share of the Saanen genes, the shear force and thermal loss of the $m$. longissimus dorsi muscle increased during baking. In the meat of the Balkan goats, $0.34 \%$ of collagen was found. It should be borne in mind that a high collagen content in muscle tissue contributes to a decrease in digestibility and, thus, results in less tenderness and lower nutritional value of the meat. In addition, collagen is a defective protein due to the lack of tryptophan and the low content of sulphur as well as aromatic amino acids [36].

Table 1. Chemical composition of goat kid meat.

\begin{tabular}{|c|c|c|c|c|}
\hline \multirow{2}{*}{ Parameters } & \multicolumn{2}{|c|}{ Breed of Goat Kids } & \multirow{2}{*}{$p$} & \multirow{2}{*}{$\begin{array}{l}\text { Significance } \\
\text { of Differences }\end{array}$} \\
\hline & Carpathian & Saanen & & \\
\hline Water (\%) & $76.92 \pm 1.245$ & $76.32 \pm 1.42$ & 0.1914 & NS \\
\hline Total solids (\%) & $23.08 \pm 1.281$ & $23.68 \pm 1.445$ & 0.1914 & NS \\
\hline Protein (\%) & $19.05 \pm 1.021$ & $20.198 \pm 1.016$ & 0.0018 & $X X$ \\
\hline Fat $(\%)$ & $2.89 \pm 0.716$ & $2.31 \pm 0.632$ & 0.0140 & $x$ \\
\hline Ash (\%) & $1.07 \pm 0.057$ & $1.10 \pm 0.051$ & 0.0728 & NS \\
\hline Carbohydrates (\%) & $0.065 \pm 0.038$ & $0.073 \pm 0.035$ & 0.5006 & NS \\
\hline $\begin{array}{l}\text { Cholesterol } \\
(\mathrm{mg} / 100 \mathrm{~g})\end{array}$ & $55.08 \pm 0.842$ & $56.79 \pm 0.659$ & 0.0000 & $X X$ \\
\hline Total collagen (\%) & $0.435 \pm 0.047$ & $0.373 \pm 0.048$ & 0.0005 & $X X$ \\
\hline
\end{tabular}

Explanations: $p$ : probability; NS: not significant; $\mathrm{X}: p<0.05 ; \mathrm{XX}: p<0.01$.

However, this did not cause any deterioration in the shear force texture parameters of the Carpathian goat meat; to the contrary, the meat was characterised by lower cutting force as well as hardness (statistically significantly lower) and chewiness, i.e., it was a tender meat (Table 2).

For sensory evaluation, roasted meat from the Carpathian goats obtained for almost all parameters (except taste desirability) higher marks compared to the meat of the Saanen goats. Biplot analysis showed that overall acceptance of meat from Carpathian goats was higher compared to Saanen goats (Figure 1). With PC1 (100\% of total variance) they were negatively loaded with taste intensity, juiciness and aroma desirability. Mean/STD plots showed differences only for juiciness, while there was no statistical differences for assessors. 
Table 2. Texture parameters and shear force value $( \pm \mathrm{SE})$ of the goat kid meat.

\begin{tabular}{|c|c|c|c|c|}
\hline \multirow{2}{*}{ Parameters } & \multicolumn{2}{|c|}{ Breed of Goat Kids } & \multirow{2}{*}{$p$} & \multirow{2}{*}{$\begin{array}{l}\text { Significance } \\
\text { of Differences }\end{array}$} \\
\hline & Carpathian & Saanen & & \\
\hline Shear force $(\mathrm{N})$ & $42.46 \pm 9.66$ & $47.4 \pm 9.08$ & 0.122451 & NS \\
\hline \multicolumn{5}{|l|}{ Texture profile: } \\
\hline Hardness (N) & $65.11 \pm 11.95$ & $75.12 \pm 15.77$ & 0.0391 & $x$ \\
\hline Springiness & $0.42 \pm 0.04$ & $0.45 \pm 0.05$ & 0.0669 & NS \\
\hline Cohesiveness & $0.46 \pm 0.05$ & $0.44 \pm 0.03$ & 0.0616 & NS \\
\hline Chewiness (N) & $12.79 \pm 3.32$ & $14.57 \pm 2.97$ & 0.0984 & NS \\
\hline Resilience & $0.18 \pm 0.04$ & $0.15 \pm 0.01$ & 0.0058 & $X X$ \\
\hline
\end{tabular}

Explanations: $p$-probability; NS-not significant; $\mathrm{X}-p<0.05 ; \mathrm{XX}-p<0.01$.

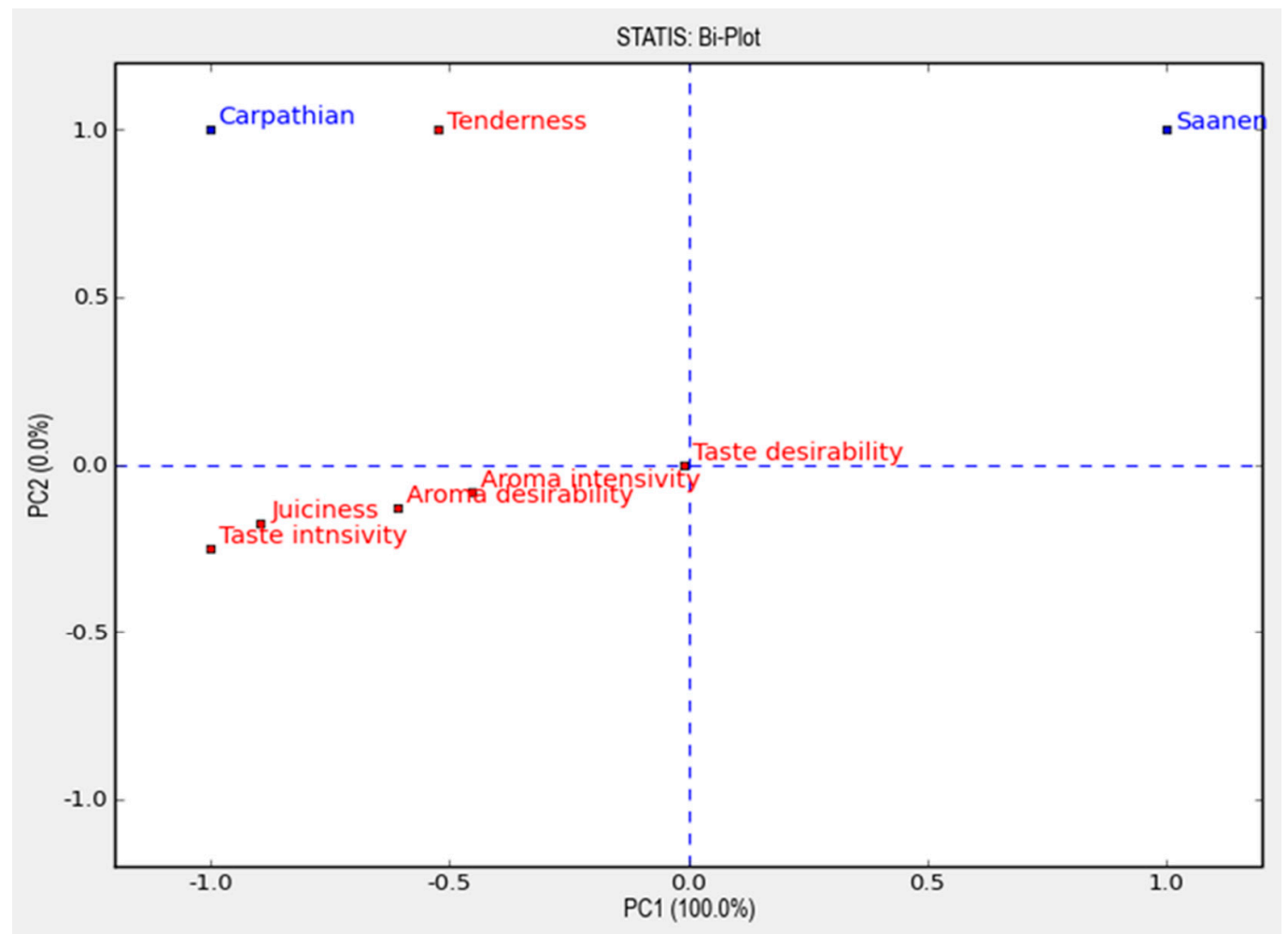

Figure 1. Biplot.

The meat cutting force for the Carpathian and the Saanen goats did not differ significantly $(p>0.05)$. According to Santos et al. (2008), the cutting force of meat from Portuguese goats was $7.7 \mathrm{~kg} / \mathrm{cm}$, while for meat from kids of the Canary Caprine Group breed, this value ranged from $43.67 \mathrm{~N}$ (10 kg live weight at slaughter) to $68.42 \mathrm{~N} \mathrm{(25} \mathrm{kg}$ live weight at slaughter) [34]. Stanišić et al. [35] showed that the goat meat of a native Serbian breed, the Balkan goat, was characterised by a lower cutting force and thermal losses compared to the meat of a crossbred goat with the increase in the share of Saanen genes in the genotype. During sensory evaluation, roasted Balkan goat meat was characterised by a more favourable smell; however, it had a poorer taste, juiciness and tenderness compared to the meat of goat kid crossbreeds. The juiciness of meat is directly associated with the content of intramuscular fat, water and collagen [35], but water, which remains in the product after cooking, has the greatest impact on juiciness during the consumption of meat [37].

In Table 3, the colour parameters of raw meat and thermal losses during cooking are presented. The colour parameters of kid goat meat of both breeds did not differ statistically $(p>0.05)$. The value of parameter $L^{*}$ of the goat meat ranged from 41.39 to 42.61 , parameter $\mathrm{a}^{*}$ from 17.51 to 17.74 and parameter $\mathrm{b}^{*}$ from 10.87 to 11.58 . Santos et al. [38], 
analysing the colour parameters of goat meat of Portuguese breeds, noted similar values: $\mathrm{L}^{*}=47.3, \mathrm{a}^{*}=17.0, \mathrm{~b}^{*}=5.2$. Bonvillani et al. [39], assessing the colour parameters of Argentine goats, also obtained similar values: $\mathrm{L}^{*}=42.7, \mathrm{a}^{*}=10.62, \mathrm{~b}^{*}=15.47$, respectively, while Kaić et al. [40], in the case of Boer kids meat, noted the following values: $L^{*}=46.18$, $a^{*}=16.64$ and $b^{*}=7.40$, respectively. These results indicate that the kid goat meat belongs to a dark red meat. Carpathian goat meat was statistically significantly lower in heat losses $(35.31 \%)$ when roasting compared to Saanen goat meat (37.14\%). According to Bonvillani et al. [39], thermal losses in the meat of Argentine goats were $24.76 \%$, while in the meat of female 4-year-old Balkan and Serbian white goats, these values were in the range of 39.41-40.60\% [41]. Liotta et al. [42] found the impact of the goat breeding system on the thermal loss of meat. Meat from male and female Messinese goats was kept exclusively outdoors and their pasture areas were characterised by the presence of Quercussuber; therefore, the animals also fed acorns (extensive system) had greater thermal losses (25.53\%) compared to males and females fed exclusively during spontaneous pasture; in the evening, the dams were kept in the stable (semi-extensive system)-they had thermal losses of $19.60 \%$. Warner-Bratzler shear force of the meat was 5.04 and $3.63 \mathrm{~kg} / \mathrm{cm}^{2}$, respectively.

Table 3. Selected quality characteristics of the analysed meat breeds.

\begin{tabular}{|c|c|c|c|c|}
\hline \multirow{2}{*}{ Parameters } & \multicolumn{2}{|c|}{ Breed of Goat Kids } & \multirow{2}{*}{$p$} & \multirow{2}{*}{$\begin{array}{l}\text { Significance } \\
\text { of Differences }\end{array}$} \\
\hline & Carpathian & Saanen & & \\
\hline \multicolumn{5}{|l|}{ Colour } \\
\hline Lightness $\left(\mathrm{L}^{*}\right)$ & $41.39 \pm 2.96$ & $42.61 \pm 3.52$ & 0.2695 & NS \\
\hline Redness $\left(a^{*}\right)$ & $17.74 \pm 1.26$ & $17.51 \pm 2.54$ & 0.7274 & NS \\
\hline Yellowness b* & $10.87 \pm 1.49$ & $11.58 \pm 2.44$ & 0.2965 & NS \\
\hline Cooking loss (\%) & $35.31 \pm 1.823$ & $37.14 \pm 2.313$ & 0.0124 & $x$ \\
\hline
\end{tabular}

Explanations: $p$ : probability; NS: not significant; $\mathrm{X}: p<0.05 ; \mathrm{XX}: p<0.01$.

Fat is a carrier of flavour-smell compounds for meat and meat products because it has the ability to dissolve flavour and smell substances. Therefore, lean meat and meat products are less tasty and juicy compared to meat and meat products with a moderate fat content. However, fat is perceived by nutritionists as the least desirable food ingredient, which is credited with the responsibility for developing so-called lifestyle diseases (chronic environmental diseases), mainly cardiovascular. In recent years, analyses of the relationship between saturated fat intake (SFA) and cardiovascular diseases (CVD) did not show statistically significant relationships [43]. Hooper et al. [44], analysing the results of 27 major research projects, showed the existence of a weak (statistically unconfirmed) relationship between the amount of consumed fat and the level of cholesterol in blood serum and the incidence of heart disease. The fatty acid profile seems to be more important. According to nutritional recommendations, the correct ratio between PUFA-MUFA should be within the range of $0.4-1$, while the ratio of n-6 PUFA to n-3 PUFA should be 2.5-8.0. In Table 4, the profile of fatty acids regarding intramuscular fat of the analysed breeds, is presented. It was reported [45] that m. semimembranosus is considered as a muscle with low fat content (compared to longissimus lumborum, psoas major and gluteus medius). The fat of Carpathian goat breeds was characterised by a higher content of monounsaturated acids, mainly C 18:1n:9 acid and a more favourable (lower) saturation index, S/P. Desaturases play a key role in the composition of the fatty acid profile in adipose tissue and animal products such as meat and milk Stearoyl-CoA desaturase is an enzyme from the class of oxidoreductase, which catalyses the formation of a fatty acid double bond between C9 and C10 [46]. Sikora et al. [47] showed that the activity of D9-desaturase in intramuscular fat was significantly greater in kids aged 90 and 180 days than in younger kids aged 60 days. The ratio of PUFA-MUFA of the analysed intramuscular fat of goats was $0.27-0.33$ and, thus, below the recommended range of 0.4-1. A more favourable ratio of n-6 PUFA to n-3 PUFA was found in the fat of the Saanen goats. Many authors, 
when analysing intramuscular fat of the goat, found a more favourable ratio of these acids, e.g., Peña et al. [48] -2.58-4.04, Peña et al. [49]—3.19-3.29, Lopes et al. [50]—1.70-3.94.

Table 4. Fatty acid composition in intramuscular fat from male kid goats (\%).

\begin{tabular}{|c|c|c|c|c|}
\hline \multirow{2}{*}{ Fatty Acids } & \multicolumn{2}{|c|}{ Breed of Goat Kids } & \multirow{2}{*}{$p$} & \multirow{2}{*}{$\begin{array}{l}\text { Significance } \\
\text { of Differences }\end{array}$} \\
\hline & Carpathian & Saanen & & \\
\hline C 10:0 & $0.12 \pm 0.03$ & $0.10 \pm 0.3$ & 0.0617 & NS \\
\hline C 12:0 & $0.18 \pm 0.03$ & $0.18 \pm 0.06$ & 0.9672 & NS \\
\hline C 14:0 & $2.40 \pm 0.64$ & $2.14 \pm 0.69$ & 0.3047 & NS \\
\hline C $14: 1$ & $0.11 \pm 0.05$ & $0.13 \pm 0.096$ & 0.4256 & NS \\
\hline C 15:0 & $0.73 \pm 0.10$ & $0.87 \pm 0.14$ & 0.0011 & $X X$ \\
\hline C 16:0 & $23.89 \pm 0.69$ & $24.56 \pm 2.29$ & 0.2398 & NS \\
\hline C $16: 1 n: 9$ & $1.02 \pm 0.15$ & $1.46 \pm 0.72$ & 0.0147 & $X$ \\
\hline C 16:1n:7 & $1.78 \pm 0.38$ & $1.50 \pm 0.15$ & 0.0064 & $X$ \\
\hline C 17:0 & $1.27 \pm 0.10$ & $1.37 \pm 0.16$ & 0.0291 & $x$ \\
\hline C $17: 1$ & $0.99 \pm 0.12$ & $0.87 \pm 0.14$ & 0.0108 & $X$ \\
\hline C 18:0 & $18.37 \pm 1.87$ & $20.21 \pm 2.34$ & 0.0137 & $x$ \\
\hline C 18:1n:9 & $35.03 \pm 1.76$ & $32.11 \pm 2.78$ & 0.0006 & $x X$ \\
\hline C $18: 1 n: 7$ & $2.48 \pm 0.13$ & $2.44 \pm 0.30$ & 0.6250 & NS \\
\hline C 18:2n:6 (LA) & $6.79 \pm 0.60$ & $6.83 \pm 2.60$ & 0.9477 & NS \\
\hline C 18:3n:6 (GLA) & $0.14 \pm 0.01$ & $0.17 \pm 0.03$ & 0.0002 & $X X$ \\
\hline C 18:3n:3(ALA) & $0.55 \pm 0.03$ & $0.67 \pm 0.17$ & 0.0041 & $X$ \\
\hline C 18:2c9t11 (CLA) & $0.62 \pm 0.28$ & $0.63 \pm 0.27$ & 0.8877 & NS \\
\hline C $20: 0$ & $0.19 \pm 0.02$ & $0.23 \pm 0.07$ & 0.0343 & $X$ \\
\hline C 20:1 & $0.07 \pm 0.01$ & $0.07 \pm 0.02$ & 0.8872 & NS \\
\hline C 20:2 & $0.06 \pm 0.03$ & $0.08 \pm 0.03$ & 0.0806 & NS \\
\hline C 20:3n:6 (DGLA) & $0.13 \pm 0.04$ & $0.13 \pm 0.08$ & 0.8473 & NS \\
\hline C 20:4n:6 (AA) & $1.86 \pm 0.66$ & $1.83 \pm 1.32$ & 0.9389 & NS \\
\hline C 20:4n:3 & $0.02 \pm 0.01$ & $0.01 \pm 0.004$ & 0.0307 & $X$ \\
\hline C 20:5n:3 (EPA) & $0.11 \pm 0.02$ & $0.15 \pm 0.09$ & 0.0731 & NS \\
\hline C 22:4n:6 & $0.21 \pm 0.05$ & $0.17 \pm 0.09$ & 0.1121 & NS \\
\hline C $22: 5 n: 6$ & $0.033 \pm 0.009$ & $0.026 \pm 0.013$ & 0.0437 & $X$ \\
\hline C 22:5n:3 (DPA) & $0.45 \pm 0.13$ & $0.53 \pm 0.28$ & 0.3047 & NS \\
\hline C 22:6n:3 (DHA) & $0.13 \pm 0.06$ & $0.31 \pm 0.27$ & 0.0106 & $X$ \\
\hline Other & $0.30 \pm 0.06$ & $0.20 \pm 0.11$ & 0.0020 & $x$ \\
\hline SFA & $47.11 \pm 0.56$ & $49.32 \pm 4.01$ & 0.0269 & $x$ \\
\hline UFA & $52.59 \pm 0.58$ & $50.68 \pm 3.89$ & 0.0297 & $x$ \\
\hline MUFA & $41.49 \pm 2.17$ & $38.35 \pm 2.18$ & 0.0001 & $X X$ \\
\hline PUFA & $11.09 \pm 1.88$ & $12.33 \pm 5.96$ & 0.4873 & NS \\
\hline n6 & $9.17 \pm 1.36$ & $9.17 \pm 4.09$ & 0.9988 & NS \\
\hline n3 & $1.26 \pm 0.24$ & $1.67 \pm 0.75$ & 0.0310 & $x$ \\
\hline $\mathrm{n} 6 / \mathrm{n} 3$ & $7.36 \pm 0.32$ & $5.52 \pm 0.20$ & 0.0000 & $X X$ \\
\hline UFA/SFA & $1.12 \pm 0.03$ & $1.04 \pm 0.16$ & 0.0481 & $X$ \\
\hline PUFA/SFA & $0.23 \pm 0.04$ & $0.27 \pm 0.15$ & 0.0166 & $x$ \\
\hline PUFA/MUFA & $0.27 \pm 0.06$ & $0.33 \pm 0.18$ & 0.2204 & NS \\
\hline DFA & $70.95 \pm 1.32$ & $70.68 \pm 3.01$ & 0.7299 & NS \\
\hline OFA & $28.74 \pm 1.33$ & $29.11 \pm 3.09$ & 0.6459 & NS \\
\hline DFA/OFA & $2.48 \pm 0.16$ & $2.46 \pm 0.35$ & 0.8892 & NS \\
\hline $\mathrm{h} / \mathrm{H}$ & $1.708 \pm 0.091$ & $1.627 \pm 0.267$ & 0.1054 & NS \\
\hline DI & $0.51 \pm 0.04$ & $0.44 \pm 0.009$ & 0.0000 & $X X$ \\
\hline $\mathrm{AI}$ & $0.51 \pm 0.02$ & $0.55 \pm 0.09$ & 0.0867 & NS \\
\hline $\mathrm{TI}$ & $1.52 \pm 0.04$ & $1.65 \pm 0.33$ & 0.1191 & NS \\
\hline
\end{tabular}


Table 4. Cont.

\begin{tabular}{cccccc}
\hline \multirow{2}{*}{ Fatty Acids } & \multicolumn{2}{c}{ Breed of Goat Kids } & & \multicolumn{2}{c}{$\begin{array}{c}\text { Significance } \\
\text { of Differences }\end{array}$} \\
\cline { 2 - 3 } & Carpathian & Saanen & & X \\
S/P & $0.85 \pm 0.02$ & $0.94 \pm 0.15$ & & 0.0166 & NS \\
A-SFA & $26.43 \pm 1.28$ & $26.88 \pm 2.99$ & & 0.5655 & X \\
T-SFA & $44.51 \pm 0.59$ & $46.69 \pm 3.76$ & & 0.0201 & XX \\
CI & $0.93 \pm 0.11$ & $1.30 \pm 0.49$ & & 0.0035 & X \\
Meat softness & $0.97 \pm 0.078$ & $0.84 \pm 0.021$ & & 0.019 & NS \\
index & $0.63 \pm 0.031$ & $0.69 \pm 0.087$ & & 0.131 & \\
NV & &
\end{tabular}

Explanations: $p$-probability; NS: not significant; X: $p<0.05 ; \mathrm{XX}: p<0.01$. LA: linoleic acid; GLA: $\gamma$ linolenic acid; ALA: $\alpha$-linolenic acid; CLA: conjugated linoleic acid; DGLA: dihomo- $\gamma$-linolenic acid; AA: arachidonic acid; EPA: eicosapentaenoic fatty acids, DHA: docosahexaenoic fatty acids; SFA: saturated fatty acids, MUFA: monounsaturated fatty acids, PUFA: polyunsaturated fatty acids, UFA: unsaturated fatty acids, DFA: hypocholesterolemic fatty acids, OFA: hypercholesterolemic fatty acids; S/P: saturation index-SFA/UFA (C14:0 + C16:0 + C18:0)/(MUFA + PUFA) [50]; AI: atherogenic index-(C12:0 + $4 \times$ C14:0 + C16:0) [(MUFA + $\Sigma$ SPUFA (n6) $+(\mathrm{n} 3)$ ] [50]; TI: thrombogenic index- $(\mathrm{C} 14: 0+\mathrm{C} 16: 0+\mathrm{C} 18: 0) \div 0.5 \times \mathrm{MUFA}+0.5 \times \mathrm{n} 6 \mathrm{PUFA}+3 \times \mathrm{n} 3 \mathrm{PUFA}$ + n3PUFA $) \div$ n6PUFA) [51]; A-SFA-(C12:0 + C14:0 + C16:0); T-SFA-(C14:0 + C16:0 + C18:0); $\Delta 9$-desaturase index-(C14:1n9 + C16:1n9 + C18:1n9) $\div(\mathrm{C} 14: 1 n 9+\mathrm{C} 18: 1 n 9+\mathrm{C} 18: 1 n 9+\mathrm{C} 14: 0+\mathrm{C} 16: 0+\mathrm{C} 18: 0)$ [52]; CI: consumer index-(C18:3 + C20:5 + C22:6) [53]; Meat softness index-(C16: $1+\mathrm{C} 18: 1) \div(\mathrm{C} 16: 0+\mathrm{C} 18: 0)$ [54]; $\mathrm{NV}$ : nutritional value of lipids- $(\mathrm{C} 12: 0+\mathrm{C} 14: 0+\mathrm{C} 16: 0) \div(\mathrm{C} 18: 1 \mathrm{c} 9+\mathrm{C} 18: 2 \mathrm{n}-6)$ [55]; h/H: ratio of hypo- and hypercholesterolemic acids- $(C 18: 1 \mathrm{c} 9+\mathrm{C} 18: 2 \mathrm{n}-6+\mathrm{C} 18: 3 \mathrm{n}-6+\mathrm{C} 18: 3 \mathrm{n}-3+\mathrm{C} 20: 2 \mathrm{n}-6+\mathrm{C} 20: 3 \mathrm{n}-6+\mathrm{C} 20: 4 \mathrm{n}-6+$

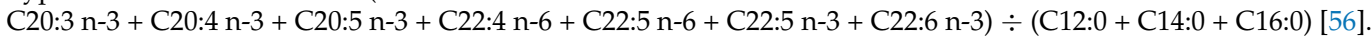

Two indices are of particular importance: TI (thrombogenicity index) and AI (atherogenicity index), which provide information as to what extent a particular element of a diet containing fatty acids affects the deepening of ischemic myocardial changes and, as a consequence, increases the risk of coronary artery disease. The higher values of these indicators, the greater the likelihood of blood clots and atherosclerosis [57]. In terms of these two indices, the intramuscular fat of Carpathian goat breeds is more favourable. The fat of ruminants is a rich source of CLA. In the analysed goat fat, $0.62-0.63 \%$ CLA was found, while Peña et al. [49] noted $0.97-1.0 \%$ CLA in fat of Criollo Cordobe goats and $0.81-0.85 \%$ in fat of Anglo Nubian kids. Horoszewicz and Pieniak-Lendzion [29] found that better parameters of the fatty acid profile were in meat obtained from animals slaughtered on the 150th day of life compared to goats slaughtered at the age of 90 days. Pieniak-Lendzion et al. [58] showed, however, that the meat of older goats (180 days) had a better sensory rating compared to the 90-day-old goats. The maintenance and nutrition system also affects the quality of the meat. In the meat of extensively kept Messinese goat breeds, Liotta et al. [42] found (pasture was characterised by the presence of Quercus suber; the animals were also fed acorn) more UFA, especially C18:1n9 and C18 2n6 acids compared to those exclusively fed on spontaneous pasture. Whereas Lopes et al. [50] showed that goats fed ad libitum, had a better quality of meat due to the lower amounts of soluble collagen and a more favourable fatty acid profile for human health with greater concentrations of oleic acids, unsaturated fatty acids and CLAs. Peña et al. [48], Madruga et al. [59] and Lopes et al. [50] demonstrated that the different goat genotypes displayed small differences in the quality of their meat and fatty acid profiles. The PUFA/SFA ratios were from $0.23 \pm 0.04$ (Carpathian) to $0.27 \pm 0.15$ (Saanen), below those suggested by Wood et al. [53], who recommended values above 0.4 to prevent illness associated with the consumption of fats. Chen and Liu [60] reported, based on the available literature, that, for meat, this ratio was 0.165 to 1.32 , however, there were a lack of data for goat meat. The highest value of this ratio in the manuscript mentioned above was found for lamb meat. Ivanović et al. [61], analysing meat from Balkan, Alpine and Saanen goats, found those ratios to be most favourable in Saanen goats in contrast to Balkan goats ( 0.071 and 0.089 , respectively). It must be mentioned that the goats were 4 years old. Sikora and Borys [62] showed a decrease in this indicator with the age of animals: 0.60 on day $60,0.30$ on day 90 and 0.196 on day 180 of slaughter, as the PUFA content dropped from 21.34 on day 60 to $8.20 \mathrm{~g} / 100 \mathrm{~g}$ of fat on day 180 . The meats present a naturally polyunsaturated-saturated 
ratio of around 0.1 [63], which implies an unbalanced consumption of desirable fatty acids (C18:3, C18:2 and C18:1). MUFA and PUFA acids (n-3 and n-6) have a positive effect on human health because they possess anti-atherosclerotic properties. In contrast, saturated fatty acids C12:0, C14:0 and C16:0 exhibit atherogenic effects (they cause an increase in the concentration of total cholesterol and LDL fractions). Furthermore, C14:0 and C16:0 as well as C18: 0 acids have a thrombogenic effect (they stimulate platelet aggregation). Therefore, the higher the values of the AI, TI, S/P and NV indices and the lower $\mathrm{h} / \mathrm{H}$, the lower the health-promoting quality of meat [64]. The above-mentioned indices in our study were not significant except $\mathrm{S} / \mathrm{P}$, but all of the meat from the Carpathian goats was characterized by more favourable values compared to the Saanen goats.

Fatty acids affect the sensory characteristics of meat; mainly softness, palatability and smell [65]. The meat softness index is defined as the ratio between (C16:1 + C18:1) and (C16: $0+\mathrm{C} 18: 0)$ [54]. The meat of Carpathian kid goats was characterised by a more favourable softness index and nutritional value of lipids. The sum of $\alpha$-linolenic acid, DHA and EPA, referred to as consumer index (CI), should not constitute more than $3 \%$ of the sum of all intramuscular fat fatty acids [53]. In the goat meat of both breeds, the value of this index ranged from 0.93 to 1.30 . The fatty acid transformation forms substances which directly affect the smell and taste of goat meat. The strong smell of goat meat is due to 4-ethylocatanoic fatty acids. This acid was detected in goat meat, lamb and mutton, as well as in cheese made from milk of these species [66]. Todaro et al. [67] claim that in addition to fatty acids, taste and aroma are also affected by other compounds: hydrocarbons, aldehydes, ketones, alcohols, furans, thiophenes, pyrrols, pyrazines, oxazoles, thiazoles and sulphurous compounds.

The nutritional and biological value of meat depends not only on protein content but mainly on amino acid composition (Table 5). The biological value of goat meat is primarily related to such essential amino acids as lysine, histidine and methionine, necessary for normal growth and development, as well as tryptophan and phenylalanine, regulating the functions of the central nervous system [31]. In the goat meat of both breeds, there were no differences between the total content of exogenous and endogenous amino acids. The EAA/NEAA ratio in the meat of the analysed breeds was similar to the results obtained by Brzostowski et al. [31]. Webb et al. [36] noted a higher EAA/NEAA ratio. Carpathian goat meat was statistically significantly higher in phenylalanine, histidine, proline, alanine and tyrosine content. According to Brzostowski et al. [31], the genotype of the kids had a significant effect on the concentrations of amino acids in meat protein. The protein of meat from crossbred kids (French Alpine $\times$ Boer), in comparison to the protein of meat from French Alpine kids, contained highly significantly more EAAs such as threonine, valine, methionine, leucine and lysine, and fewer NEAAs, such as glutaminic acid, glycine and alanine. It follows that the proportions and ratios of EAAs and NEAAs in the protein of meat from crossbreeds were more desirable than in the protein of meat from pure breeds $(p \leq 0.05)$. An important quality of meat is the content of amino acids with glucogenic, ketogenic and glucoketogenic effects. This division was made due to metabolic changes in the body. Glucogenic amino acids are such that they can be converted into glucose by gluconeogenesis. Glucogenic amino acids include: serine, histidine, arginine, cysteine, proline, alanine, glutamic acid, glutamine, aspartic acid, asparagine and methionine. Ketogenic amino acids are those that can be converted into ketone bodies in the process of ketogenesis, the formation of ketone bodies as an alternative oxidation product of free fatty acids in the liver. This group includes leucine and lysine. Glucogenic and ketogenic amino acids are: isoleucine, threonine, phenylalanine, tyrosine and tryptophan. In the meat from Carpathian goat kids, statistically significantly more glucogenic amino acids such as histidine, proline and alanine were found, while in the meat of the Saanen goats, there was statistically significantly more serine and methionine. The differences in content of ketogenic amino acids in goat meat of both breeds were not of statistical significance. 
Table 5. Amino acid profile of protein in meat from male kid goats (\%).

\begin{tabular}{ccccc}
\hline Amino Acids & \multicolumn{2}{c}{ Breed of Goat Kids } & $p$ & $\begin{array}{c}\text { Significance } \\
\text { of Differences }\end{array}$ \\
\hline Threonine & $5.38 \pm 0.40$ & $5.54 \pm 0.36$ & 0.2173 & NS \\
Valine & $5.92 \pm 0.10$ & $5.96 \pm 0.26$ & 0.6583 & NS \\
Methionine & $3.07 \pm 0.06$ & $3.16 \pm 0.13$ & 0.0124 & $\mathrm{X}$ \\
Isoleucine & $5.37 \pm 0.26$ & $5.26 \pm 0.13$ & 0.1163 & $\mathrm{NS}$ \\
Leucine & $9.38 \pm 0.48$ & $9.38 \pm 0.28$ & 0.9988 & $\mathrm{NS}$ \\
Phenylalanine & $4.88 \pm 0.46$ & $4.55 \pm 0.39$ & 0.0283 & $\mathrm{X}$ \\
Histidine & $3.26 \pm 0.21$ & $2.99 \pm 0.27$ & 0.0021 & $\mathrm{XX}$ \\
Lysine & $9.67 \pm 0.70$ & $9.98 \pm 0.63$ & 0.1620 & $\mathrm{NS}$ \\
Total EAAs & $46.94 \pm 1.41$ & $46.82 \pm 0.55$ & 0.7491 & $\mathrm{NS}$ \\
Aspartic acid & $9.33 \pm 0.21$ & $9.61 \pm 0.57$ & 0.0565 & $\mathrm{NS}$ \\
Serine & $3.73 \pm 0.15$ & $3.89 \pm 0.21$ & 0.0127 & $\mathrm{X}$ \\
Glutamic acid & $14.97 \pm 0.67$ & $15.07 \pm 0.53$ & 0.6137 & $\mathrm{NS}$ \\
Proline & $4.19 \pm 0.23$ & $3.85 \pm 0.34$ & 0.0010 & $\mathrm{XX}$ \\
Glycine & $4.11 \pm 0.88$ & $4.48 \pm 0.39$ & 0.1173 & $\mathrm{NS}$ \\
Alanine & $6.03 \pm 0.25$ & $5.82 \pm 0.27$ & 0.0212 & $\mathrm{X}$ \\
Tyrosine & $4.01 \pm 0.20$ & $3.76 \pm 0.43$ & 0.0323 & $\mathrm{X}$ \\
Arginine & $6.70 \pm 0.15$ & $6.71 \pm 0.19$ & 0.9717 & NS \\
Total NEAAs & $53.06 \pm 1.41$ & $53.18 \pm 0.55$ & 0.7353 & NS \\
EAAs/NEAAs & $0.89 \pm 0.05$ & $0.88 \pm 0.02$ & 0.6848 & $\mathrm{NS}$ \\
\hline
\end{tabular}

Explanations: $p$ : probability; NS: not significant; $\mathrm{X}: p<0.05 ; \mathrm{XX}: p<0.01$.

\section{Conclusions}

Comparing the meat of the male goat kids slaughtered at 150 days of age, it was found that the meat of the Carpathian goat is characterised by a lower content of protein and cholesterol and a greater variety of ingredients and collagen in comparison to the meat of Saanen goats. Despite the higher collagen content, the goat meat of Carpathian breeds is characterised by a lower tensile strength and less hardness and chewiness, it is a more delicate meat. Carpathian goat fat is characterised by a higher content of monounsaturated acids, mainly C 18:1n:9 and a more favourable (lower) value of the saturation index, S/P. In the goat meat of both breeds, no differences were found between the total content of exogenous and endogenous amino acids. The EAA/NEAA ratio in the meat of the analysed breeds was $0.88-0.89$. However, meat from the Carpathian goats are characterised by statistically significantly higher content of phenylalanine, histidine, proline, alanine and tyrosine in comparison with meat from the Saanen goats. The obtained results confirm the high quality of the meat of the local Carpathian breed in comparison to the Saanen breed.

Author Contributions: Conceptualization, W.M., A.K., J.S. and Ł.M.; Analysis, W.M. and Ł.M.; Writing-original draft preparation, W.M. and Ł.M.; Writing—review and editing, W.M., Ł.M., A.K. and J.S. All authors have read and agreed to the published version of the manuscript.

Funding: The project "The uses and the conservation of farm animal genetic resources under sustainable development" is co-financed by the National Centre for Research and Development within the framework of the strategic R \& D programme "Environment, agriculture and forestry"-BIOSTRATEG, contract number: BIOSTRATEG2/297267/14/NCBR/2016.

Institutional Review Board Statement: This study did not require ethical approval because all the procedures were breeding procedures. Slaughter was conducted at the authorized slaughterhouse, following the normal commercial procedure.

Informed Consent Statement: Not applicable.

Data Availability Statement: Data available on request due to restrictions eg privacy or ethical.

Conflicts of Interest: The authors declare no conflict of interest. 


\section{References}

1. Skapetas, B.; Bampidis, V. Goat production in the World: Present situation and trends. Livest. Res. Rural Dev. 2016, 28, 200. Available online: http:/ / www.lrrd.org/lrrd28/11/skap28200.html (accessed on 1 March 2021).

2. EUROSTAT Agricultural Production-Livestock and Meat. Available online: http://appsso.eurostat.ec.europa.eu/nui/show.do? dataset=apro_mt_lsgoat\&lang=en (accessed on 1 March 2021).

3. Weź udział w Narodowym Spisie Powszechnym Ludności i Mieszkań. 2021. Available online: www.stat.gov.pl (accessed on 1 March 2021).

4. Sikora, J.; Kawęcka, A.; Walinowicz, K. Characteristic of genetic structure of goats in Poland. Sci. Ann. Pol. Soc. Anim. Prod. 2011, 7, 19-25.

5. Bernacka, H.; Peter, E.; Kasperska, D.; Mistrzak, M. Performance evaluation of Alpine and Saanen goats in Poland in the years 2000-2011. Pol. Nat. Sci. 2013, 28, 339-348.

6. Polish Union of Sheep-Farmers (PUSF). Sheep and Goat Breeding in Poland in 2019; PUSF: Warsaw, Poland, 2020. (In Polish)

7. Bagnicka, E.; Sikora, J.; Kaba, J.; Łukaszewicz, M.; Gruszecki, T. Current problems of dairy goat breeding in Poland. Wiadomości Zootechniczne 2017, 2, 61-76. (In Polish)

8. Jawor, G. Seasonal pastoral exploitation of forests in the area of Subcarpathia in the 15th and 16th century. Balc. Posnaniensia Acta Stud. 2016, 23, 175. [CrossRef]

9. Trybulski, M. Goats. Origin, Habit, Breed, Breeding, Nutrition and Diseases; Księgarnia Rolnicza: Warsaw, Poland, 1939. (In Polish)

10. Sikora, J.; Kawęcka, A.; Puchała, M. Restitution forgotten goat breeds as an example of enriching farm animal biodiversity. In Proceedings of the International Congress on Sheep and Goats-Farmers and Scientists Create Future, WCCB, Bonn, Germany, 15-16 October 2020; p. 80, Book of abstracts.

11. Călin, I.; Răducuţă, I.; Dărăban, S.; Vlad, I.; Priseceanu, H.I.; Pascal, C.; Pădeanu, I. Research on Quantitative Skills in Meat Production Direction at Youth Goats from Carpathian Breed in Relation with the Rearing System. Agric. Agric. Sci. Procedia 2015, 6, 191-196. [CrossRef]

12. Kawęcka, A.; Pasternak, M. Boer goats in Poland-analysis of the breeding condition and characteristics of selected per-formance parameters over the last decade. Sci. Ann. Anim. Sci. 2020, 47, 225-234.

13. Directive 2010/63/EU of the European Parliament and of the Council of 22 September 2010 on the Protection of Animals Used for Scientific Purposes. 02010L0063-EN—26.06.2019—001.001-1. Available online: https:/ / eur-lex.europa.eu/legal-content/ EN/TXT/PDF/?uri=CELEX:02010L0063-20190626\&rid=5 (accessed on 1 March 2021).

14. NRIAP. Assessment of the Utility of Lamb Meat According to the Requirements and Methods Used in the European Union Countries; NRIAP: Cracow, Poland, 2009; p. 32. (In Polish)

15. PN-ISO 1442:2000. Meat and Meat Products. Water Contents Determination; Polish Committee for Standardization: Warsaw, Poland, 2000.

16. PN-ISO 1444:2000. Meat and Meat Products. Free Fat Contents Determination; Polish Committee for Standardization: Warsaw, Poland, 2000.

17. PN-75/A-04018:1975/Az3:2002. Agricultural Food Products. Nitrogen Contents Determination with Kjeldahl's Method and Recalculation into Protein; Polish Committee for Standardization: Warsaw, Poland, 2002.

18. PN-ISO 936:2000. Meat and Meat Products. Determination of Total Ash Content; Polish Committee for Standardization: Warsaw, Poland, 2000.

19. PN-ISO 3496:2000. Meat and Meat Products. Determination of Hydroxyproline Content; Polish Committee for Standardization: Warsaw, Poland, 2000.

20. Folch, J.; Lees, M.; Stanley, G.H.S. Asimple method for the isolation and purification of lipids from animal tissue. J. Biol. Chem. 1957, 226, 497-509. [CrossRef]

21. AOAC. Official Methods of Analysis, 16th ed.; Association of Official Analytical Chemists: Washington, DC, USA, 1995.

22. PN-ISO 4121:1998. Sensory Analysis-Methodology-Evaluation of Food Products Using Scaling Methods; Polish Committee for Standardization: Warsaw, Poland, 1998.

23. PN-ISO 6658:1998. Sensory Analysis-Methodology-General Guidelines; Polish Committee for Standardization: Warsaw, Poland, 1998.

24. ISO 8586:2014. Sensory Analysis. General Guidelines for the Selection, Training and Monitoring of Selected Assessors and Expert Sensory Assessors; International Organization for Standardization: Geneva, Switzerland, 2014.

25. Statistica 6.0. StatSoft, 2003. Available online: https://www.statsoft.pl/ (accessed on 1 May 2021).

26. Rhee, K.; Waldron, D.; Ziprin, Y. Fatty acid composition of goat diets vs intramuscular fat. Meat Sci. 2000, 54, 313-318. [CrossRef]

27. Madruga, M.S.; Narain, N.; Souza, J.G.; Costa, R.G. Castration and slaughter effects on fat components of "mestiço" goat meat. Small Rumin. Res. 2001, 42, 77-82. [CrossRef]

28. Madruga, M.S.; Resosemito, F.S.; Narain, N.; Souza, W.H.; Cunha, M.G.G.; Ramos, J.L.F. Effect of raising conditions of goats on physico-chemical and chemical quality of its meat efecto de las condiciones de crecimiento de cabras en la calidad fisico-química y química de su carne. Cienc. y Tecnol. Aliment. 2006, 5, 100-104. [CrossRef]

29. Horoszewicz, E.; Pieniak-Lendzion, K. Health qualities of meat of the meat of the white improved breed kids according to the age of slaughtered goats. Acta Sci. Pol. Zootech. 2008, 7, 11-18.

30. Borgogno, M.; Corazzin, M.; Saccà, E.; Bovolenta, S.; Piasentier, E. Influence of familiarity with goat meat on liking and preference for capretto and chevon. Meat Sci. 2015, 106, 69-77. [CrossRef] [PubMed] 
31. Brzostowski, H.; Niżnikowski, R.; Tański, Z. Quality of goat meat from purebred French Alpine kids and Boer crossbreeds. Arch. Anim. Breed. 2008, 51, 381-388. [CrossRef]

32. Kalinowska, B.; Pustkowiak, H. The fatty acid profile and cholesterol content of meat and organ sof kids fattenet to $16 \mathrm{~kg}$. Sci. J. Agric. Acad. Wrocław 2000, 399, 165-168. (In Polish)

33. Patli, A.D.; Kurhe, B.P.; Phalak, K.R.; Dhoble, R.L. Influence of synchronization treatmens on serum total protein and cholesterol levels in Osmanabadi goats. Indian J. Anim. Rep. 2000, 21, 103-104.

34. Marichal, A.; Castro, N.; Capote, J.; Zamorano, M.J.; Arguello, A. Effects of live weight at slaughter (6, 10 and $25 \mathrm{~kg})$ on kid carcass and meat quality. Livest. Prod. Sci. 2003, 83, 247-256. [CrossRef]

35. Stanišić, N.; Žujović, M.; Tomić, Z.; Maksimović, N.; Bijelić, Z.; Ivanovic, S.; Memisi, N. The Effects of Crossing Balkan and Saanen Goat Breeds on Carcass Traits and Certain Quality Parameters of Kid Meat. Ann. Anim. Sci. 2012, 12, 53-62. [CrossRef]

36. Janicki, B.; Buzała, M. Effect of collagen on technological quality of meat. Food Sci. Technol. Qual. 2013, 2, 19-29. [CrossRef]

37. Webb, E.C.; Casey, N.; Simela, L. Goat meat quality. Small Rumin. Res. 2005, 60, 153-166. [CrossRef]

38. Santos, V.A.C.; Silva, S.; Azevedo, J.M.T. Carcass composition and meat quality of equally mature kids and lambs1. J. Anim. Sci. 2008, 86, 1943-1950. [CrossRef] [PubMed]

39. Bonvillani, A.; Peña, F.; Domenech, V.; Polvillo, O.; Garc, P.T.; Casal, J.J. Meat quality of Criollo Cordobes goat kids pro-duced under extensive feeding conditions. Effects of sex and age/weight at slaughter. Span. J. Agric. Res. 2010, 8, 116-125. [CrossRef]

40. Kaić, A.; Cividini, A.; Potočnik, K. The effect of sex and age at slaughter on some carcass and meat quality traits of Boer kids. Acta Vet. 2013, 63, 201-210. [CrossRef]

41. Ivanovic, S.; Stojanovic, Z.; Nesic, K.; Pisinov, B.; Baltic, M.; Popov-Raljic, J.; Djuric, J. Effect of goat breed on the meat quality. Chem. Ind. 2014, 68, 801-807. [CrossRef]

42. Liotta, L.; Chiofalo, V.; Presti, V.L.; Chiofalo, B. Effect of production system on growth performances and meat traits of suckling Messinese goat kids. Ital. J. Anim. Sci. 2020, 19, 245-252. [CrossRef]

43. Chowdhury, R.; Warnakula, S.; Kunutsor, S.; Crowe, F.; Ward, H.A.; Johnson, L.; Franco, O.H.; Butterworth, A.S.; Forouhi, N.G.; Thompson, S.G.; et al. Association of dietary, circulating, and supplement fatty acids with coronary risk: A systematic review and meta-analysis. Ann. Intern. Med. 2014, 160, 398-406. [CrossRef]

44. Hooper, L.; Summerbell, C.D.; Higgins, J.P.T.; Thompson, R.L.; Capps, N.E.; Davey Smith, G.; Reimersma, R.A.; Ebrahim, S. Dietary fatintake and prevention of cardiovascular disease: Systematic review. Br. Med. J. 2001, 322, 757-763. [CrossRef]

45. Hwang, Y.-H.; Joo, S.-H.; Bakhsh, A.; Ismail, I.; Joo, S.-T. Muscle Fiber Characteristics and Fatty Acid Compositions of the Four Major Muscles in Korean Native Black Goat. Food Sci. Anim. Resour. 2017, 37, 948-954. [CrossRef]

46. Kucharski, M.; Kaczor, U. Stearoyl-CoA desaturase-The lipid metabolism regulator. Adv. Hyg. Exp. Med. 2014, 68, 334-342. [CrossRef] [PubMed]

47. Sikora, J.; Borys, B.; Borys, A. Activity of 89 -desaturase in intramuscular fat of fattened goat kids according to breed and age. Pol. J. Nat. Sci. Suppl. 2007, 4, 97-100.

48. Peña, F.; Bonvillani, A.; Freire, B.; Juárez, M.; Perea, J.; Gómez, G. Effects of genotype and slaughter weight on the meat quality of Criollo Cordobes and Anglonubian kids produced under extensive feeding conditions. Meat Sci. 2009, 83, 417-422. [CrossRef] [PubMed]

49. Peña, F.; Juárez, M.; Bonvillani, A.; García, P.; Polvillo, O.; Domenech, V. Muscle and genotype effects on fatty acid composition of goat kid intramuscular fat. Ital. J. Anim. Sci. 2011, 10, e40. [CrossRef]

50. Lopes, L.; Martins, S.; Chizzotti, M.; Busato, K.; Oliveira, I.; Neto, O.M.; Paulino, P.; Lanna, D.; Ladeira, M. Meat quality and fatty acid profile of Brazilian goats subjected to different nutritional treatments. Meat Sci. 2014, 97, 602-608. [CrossRef] [PubMed]

51. Ulbricht, T.L.; Southgate, D.A. Coronary heart disease: Seven dietary factors. Lancet 1991, 338, 985-992. [CrossRef]

52. Smith, S.B.; Hively, T.S.; Cortese, G.M.; Han, J.J.; Chung, K.Y.; Casteñada, P.; Gilbert, C.D.; Adams, V.L.; Smith, S.B. Conjugated linoleic acid depresses the $\Delta 9$ desaturase index and stearoyl coenzyme A desaturase enzyme activity in porcine adipose tissue. J. Anim. Sci. 2002, 80, 2110-2115.

53. Wood, J.D.; Richardson, R.I.; Nute, G.R.; Fisher, A.V.; Campo, M.; Kasapidou, E.; Sheard, F.P.; Enser, M. Effects of fatty acids on meat quality: A review. Meat Sci. 2004, 66, 21-32. [CrossRef]

54. Todaro, M.; Corrao, A.; Barone, C.M.A.; Schinelli, R.; Occidente, M.; Giaccone, P. The influence of age and litter size onsome quality traits of kid meat. Small Rumin. Res. 2002, 44, 75-80. [CrossRef]

55. Estévez, M.; Morcuende, D.; Ramírez, R.; Ventanas, S.; Cava, R. Extensively reared Iberian pigs ver-sus intensively reared white pigs for the manufacture of liver pâté. Meat Sci. 2004, 67, 453-461. [CrossRef]

56. Santos-Silva, J.; Bessa, R. Effect of genotype, feeding system and slaughter weight on the quality of light lambs. Livest. Prod. Sci. 2002, 77, 187-194. [CrossRef]

57. Donovan, D.; Schingoethe, D.; Baer, R.; Ryali, J.; Hippen, A.; Franklin, S. Influence of Dietary Fish Oil on Conjugated Linoleic Acid and Other Fatty Acids in Milk Fat from Lactating Dairy Cows. J. Dairy Sci. 2000, 83, 2620-2628. [CrossRef]

58. Pieniak-Lendzion, K.; Niedziółka, R.; Szeliga, W. Comparison of slaughter value and some quality traits of ram lambs and goat kids. Ann. Anim. Sci. 2003, 3, 35-40.

59. Madruga, M.S.; De Medeiros, E.J.L.; De Sousa, W.H.; Cunha, M.D.G.G.; Filho, J.M.P.; Queiroga, R.D.C.R.D.E. Chemical composition and fat profile of meat from crossbred goats reared under feedlot systems. Rev. Bras. Zootec. 2009, 38, 547-552. [CrossRef] 
60. Chen, J.; Liu, H. Nutritional Indices for Assessing Fatty Acids: A Mini-Review. Int. J. Mol. Sci. 2020, 21, 5695. [CrossRef] [PubMed]

61. Ivanović, S.; Pavlović, M.; Pavlović, I.; Tasić, A.; Janjić, J.; Baltić, M. Influence of breed on selected quality parameters of fresh goat meat. Arch. Anim. Breed. 2020, 63, 219-229. [CrossRef] [PubMed]

62. Sikora, J.; Borys, B. Lipid profile of intramuscular fat in kids fattened to 60, 90 and 180 days of age. Arch. Tierz. 2006, 49, 193-200.

63. Williams, C.M. Dietary fatty acids and human health. Anim. Res. 2000, 49, 165-180. [CrossRef]

64. FAO. Fats and fatty acids in human nutrition. Report of an expert consultation. FAO Food Nutr. Pap. 2010, 91, 1-166.

65. Niedziółka, R.; Pieniak-Lendzion, K. Preliminary research on correlation sbetween the level of selected fatty acids and sensory evaluation of goat ling and ram meat. Żywność 2005, 3, 169-176. (In Polish)

66. Ivanovic, S.; Nesic, K.; Pisinov, B.; Pavlovic, I. The impact of diet on the quality of fresh meat and smoked ham in goat. Small Rumin. Res. 2016, 138, 53-59. [CrossRef]

67. Todaro, M.; Corrao, A.; Alicata, M.; Schinelli, R.; Giaccone, P.; Priolo, A. Effects of litter size and sex on meat quality traits of kid meat. Small Rumin. Res. 2004, 54, 191-196. [CrossRef] 